\title{
Critical thinking, literature and teachers' instructional activities: An Indonesian case of community service program for English teachers
}

\author{
Isti Siti Saleha Gandana ${ }^{\mathrm{a}, 1, *}$, Nia Nafisah ${ }^{\mathrm{b}, 2}$, Ernie D. Ayu Imperiani ${ }^{\mathrm{b}, 3}$ \\ a Universitas Pendidikan Indonesia, Jl. Dr. Setiabudi No. 229, Bandung 40154, Indonesia \\ ${ }^{\mathrm{b}}$ Universitas Pendidikan Indonesia, Jl. Dr. Setiabudhi No. 229, Bandung 40154, Indonesia \\ ${ }^{1}$ istigandana@upi.edu*; ${ }^{2}$ n_nafisah@upi.edu; ${ }^{3}$ ernie_imperiani@upi.edu \\ * corresponding author
}

ARTICLE INFO

Article history

Received 29 June 2021

Revised 21 July 2021

Accepted 20 August 2021

Keywords

critical thinking

EFL classroom

instructional activities

literature

\section{ABSTRACT}

Critical thinking (CT) has generally been known as one of the core competencies of the 21 st-century skills that students need to acquire to succeed in today's world. To attain this goal, teachers undoubtedly have a critical role to play. Involving a group of Indonesian teachers of English, this study aims to explore the teachers' initial conceptions of critical thinking as reflected in their planned classroom activities. Specifically, the data collected were in the form of written instructional activities that used literary works as learning materials. These data were obtained following the teachers' participation in an online workshop on promoting critical thinking through literature held for English teachers from MGMP (i.e., English Teachers Working Group) in Bandung Regency. The workshop introduced a model of teaching critical thinking skills using literary works and required the teachers to design their own instructional activities based on the proposed CT model. Adopting content analysis as the methodological tool to scrutinize the teachers' prepared materials, our initial findings indicate that, in general, the teachers had inadequate knowledge of how to incorporate critical thinking skills into their teaching. Literature was seen merely as a tool to develop students' linguistic abilities rather than as a way to explore humans' experiences and to connect 'the word and the world'. This study recommends that the teachers be given more time to better explore the concepts surrounding critical literacy pedagogy as well as be given more opportunities for practical application of the promoted instructional model.

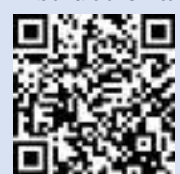

This is an open access article under the CC-BY-SA license.

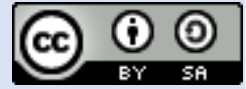

How to Cite: Gandana, I.S.S., Nafisah, N., \& Imperiani, E. D. A., (2021). Critical thinking, literature and teachers' instructional activities: An Indonesian case of community service program for English teachers. English Language Teaching Educational Journal, 4(2), 138-147

\section{Introduction}

The $21^{\text {st }}$ century presents opportunities and challenges like no other centuries did. On the one hand, it offers exciting opportunities such as global networks and innovations. On the other hand, however, it challenges life as issues of inequalities and inequities, especially in relation to global opportunities, becomes ever more pressing. Moreover, with the bombardment of information on a daily basis, it becomes very challenging to decide what is true and what is untrue. The circulation of fake news can, indeed, be very harmful to those who lack the ability to distinguish facts from opinions or to those who are not willing to look beyond what a text has to offer. In light of these challenges and opportunities, the ability to think critically, then, becomes of paramount importance, 
as it equips people with the skills to evaluate the quality of texts that are presented to them. According to Facione (2015) critical thinking consists of cognitive skills and dispositions. A critical thinker should be able to interpret, analyze, evaluate, infer, and self-regulate a problem or a case presented in inquisitive, systematic, and seeking truth manners. Hence, in this era of influx information, critical thinking has been regarded as part of the $21^{\text {st }}$ century skills that students are required to attain (Saleh, 2019). Consequently, critical thinking skills have been incorporated into the national curriculum so as to prepare Indonesian students to meet the challenges of the $21 \mathrm{st}$ century through its Regulation of the Republic of Indonesia Number 17 Year 2010 Regarding Educational Management and Administration. Hence, it implies that fostering critical thinking skills lies mostly in the shoulders of the teachers.

\subsection{Literature and Teaching Critical Thinking Skills}

Much of literature on teaching critical thinking skills addresses teaching strategies and teacher's role and perception. Regarding the teaching strategies, a number of research have indicated that critical thinking can be incorporated into many different subjects such as sciences, physical education, and language and arts. Interestingly, these studies have shown that the use of literary texts often provide more opportunities in cultivating critical thinking skills. Literature, which includes poetry, prose, provides access to cultural aspects, encourages language acquisition and language awareness, develops students' interpretive abilities, and educates the whole person (Ahmad, Zainal \& Rajab, 2019; Küçükoğlu \& Arikan, 2011). By reading literature, students are expected to pay attention to details, to suspend judgments before examining assumptions, to make decisions based on their judgments, and to look for possible alternatives and solutions. This is in vein with the ability and disposition expected in critical thinkers. In reading literature, students are required to demonstrate abilities to recall, to differentiate facts from opinions, to understand the literal and implied meanings, to be perceptive and make moral reasoning, and finally to connect and apply what they have learned from the texts to other domains or real life situations (Abudlridha \& Latiff, 2020). Employing suitable strategies, teachers can scaffold students' understanding of a passage or a story so that they become critical; this can be done by identifying facts, analysing the issues in the text, questioning unfounded statements, discussing real life issues, and providing the opportunity for students to create their own texts (Bobkina \& Stefanova, 2016; Tabačkovà, 2015). Furthermore, a study by Ilyas (2015) finds that the incorporation of literary texts in English textbooks for Indonesian middle school levels provides more critical thinking questions and activities than other texts. The findings from this body of research emphasize the strength of literary texts to develop students' critical thinking.

Besides teaching strategies, many studies on critical thinking focus on teachers' roles and perceptions. As agents of change, teachers should be able to promote and improve critical thinking skills with every possible means available. On one hand, research suggests that critical thinking should be taught explicitly and that instructors who received training in teaching critical thinking showed to have better results in improving students' critical thinking skills, regardless of cultures and disciplines (Abrami, et.al, 2015; Bobkina \& Stefanova, 2016; Deering, 2018; Liao, 2016; Nold, 2017; Tabačkovà, 2015). On the other hand, teachers' perceptions and practices regarding critical thinking vary even in the same country. Despite the models and the success stories of using literature, some have pointed out the discrepancies of teachers' perceptions and practices with regard to critical thinking, which, in turn, may hinder the students' enhancement of the skills. Mok and Yuen (2016), for instance, reveal that Hong Kong teachers in their study understand critical thinking but overlook bias and context-sensitivity. Meanwhile, Saleh (2019) and Shpeizer (2018) focus on the challenges the teachers face in implementing critical thinking in the classroom. The challenges are greater when the teachers have vague concept of critical thinking. The discrepancy of understanding of critical thinking may lead to students' poor critical thinking performance (Enciso, Enciso \& Daza, 2017; Ilyas, 2018; Shpeizer, 2018). These studies indicate that teachers are pivotal in developing students' critical thinking. Without rigorous training for teachers, it is very unlikely that there is a significant change in students' critical ability and disposition as expected.

\subsection{Teaching Critical thinking in Indonesian Context}

Reviewing from the findings of studies above, little is known about the practice of teaching critical thinking skills in Indonesian context. Although Ilyas (2015) confirms the benefits of literature to develop critical thinking skills, many Indonesian-based research do not use literary texts and tend to rely on applying a particular strategy or technique which is considered in line with 
critical thinking skills. In addition, report on success of teaching critical thinking is measured through quantitative data analysis (Bustami \& Corebima, 2017; Hasnunidah et.al., 2015; Maknun, 2019; Syahrial et.al, 2019). This implies two notions: 1) literary texts are not popular approach to teach critical thinking; 2) success is a fait accompli regardless the teachers' competence and perception on the concept of critical thinking. Such implication can be seen in the practice of workshops on critical thinking skills which we observed so far. The workshops rarely introduce literature, which previous studies proved to be significantly influential, to develop critical thinking skills. In addition, the workshops overlook the teachers' ability and perceptions on the concept of critical thinking. Studies by Ilyas (2015) and Solihati and Hikmat (2018) indicate that Indonesianpublished school textbooks lack engagement with critical thinking skills. It follows that many teachers in the country are not sufficiently equipped with the necessary tools to promote the development of students' critical thinking skills. To contribute to this important area, we ran a workshop for teachers on how to incorporate critical thinking skills into their instructional activities through the use of literary texts. Using the critical thinking model (henceforth is abbreviated into CT model) developed by Bobkina and Stefanova (2016), this paper examines the teachers' understanding of the model as reflected in their instructional design.

\subsection{A Model for Teaching Critical Thinking Skills}

Prior to elaborating the CT model we adopted in our community service program for the English teachers, it is important to acknowledge that the model has been drawn on the New London Group's (1996) pedagogy of multiliteracies. Multiliteracies pedagogy emerged as a response to changes in the way the concept 'literacy' is perceived due to globalizing forces, such as communications technologies, which have opened up diverse modes of communication as well as linguistic expressions and representations. The pedagogy of multiliteracy, thus, extends beyond the monolingual and monocultural literacy pedagogy that revolved around traditional reading and writing and takes into account the proliferating diverse modes of meaning making. This new literacy pedagogy was aimed, among others, at meeting the students' changing needs to be able to effectively function and navigate within these multiple modes of communication (Willis Allen \& Paesani, 2010). To do so, the multiliteracies approach embraces four key curricular components: (1) situated practice, (2) overt instruction, (3) critical framing, and (4) transformed practice.

The first component, situated practice, refers to "immersion in language use" (in Bobkina \& Stefanova, 2016, p. 686). The focus here is students' thoughts and opinions, which may relate to their lives and experiences. The second component, overt instruction, deals with understanding of the text in a systematic, analytic and conscious manner, allowing students to construct meaning out of the text. The third component, critical framing, involves "the reflective dimension of literacy instruction" (ibid.), connecting the linguistic aspect to wider communicative and sociocultural contexts. The last component, transformed practice refers to the reshaping of the text and the changing of mode of representation. These four components are adopted by Bobkina and Stefanova (2016) as four stages upon which critical thinking skills are built.

Due to its systematic as well as easy-to-follow and executable stages, Bobkina and Stefanova's CT model has, consequently, been used in our community service program to help the teacher participants involved develop their students' critical thinking skills. In familiarizing the CT model to the teachers, we hope that they will, later on, adopt and incorporate the model into their actual classroom practice. In view of this, it is, therefore, important to investigate the extent to which the teacher participants have understood the concepts surrounding the CT model and how to design classroom activities based on the model, incorporating the four key stages into their instructional planning. While the issue of critical thinking skills has so often been raised in the education context, much of the focus has been given to students; not many workshops, however, have been given to raise the teachers' own critical thinking abilities despite the fact that they are among the key players in the educational landscape. This study is, therefore, expected to contribute to the literature on teachers' professional development pertaining to their critical literacy practices in the Indonesian context.

\section{Method}

This qualitative case study is primarily concerned with answering the following research question: to what extent do the teacher participants exhibit an understanding of the CT model as 
reflected in their planned instructional activities? The community service conducted was in the form of workshops. The initial plan was to run the workshops face-to-face. However, due to the COVID-19 outbreak, online sessions became our only option. The workshops were carried out twice, on $21^{\text {st }}$ and $30^{\text {th }}$ April 2020 via Google Meet, and the duration for each session was approximately three hours. We chose literary texts as the medium to teach critical thinking skills for two main reasons: first, because we, the instructors, are from the English Language and Literature Study Program, and, second, because our professional experiences have shown literary texts to provide rich opportunities and resourceful space for engaging students with 'the word and the world' (Freire \& Macedo, 1987). In the first workshop, we focused on familiarizing the teachers with the concepts surrounding critical thinking and on providing detailed explanation of the four stages of the CT model. To check the teachers' understanding of the model, they were given an assignment to design their own instructional activities based on the model discussed using any literary texts of their own choice. They were given a week to complete their written assignments. In the second workshop, our primary focus was on discussing the teachers' assignments and on giving detailed, one-on-one feedback. The assignments then became the data source for this study.

Table 1. The Participants' Profiles

\begin{tabular}{clcll}
\hline No. & Pseudonym & $\begin{array}{c}\text { Gender } \\
\text { (Male/ } \\
\text { Female) }\end{array}$ & \multicolumn{1}{c}{ Teaching experience } & Institutional affiliation \\
\hline 1 & Ari & M & 1 year, 1 month & Public junior high school \\
2 & Apep & M & 12 years & Public junior high school \\
3 & Ayu & F & 16 years, 9 months & Private junior high school \\
4 & Iin & F & 22 years & Public junior high school \\
5 & Endah & F & 22 years, 9 months & Public junior high school \\
6 & Ela & F & 19 years & Public junior high school \\
7 & Intan & F & 4 years & Private junior high school \\
8 & Leni & F & 17 years, 9 months & Public junior high school \\
9 & Meti & F & 10 years, 3 months & Public junior high school \\
10 & Nandang & M & 10 years & Public junior high school \\
11 & Nani & F & 16 years, 10 months & Private junior high school \\
12 & Permatasari & F & 10 years & Public junior high school \\
13 & Setianingsih & F & 27 years & Public junior high school \\
14 & Tika & F & 24 years, 4 months & Public junior high school \\
15 & Vira & F & 15 years, 9 months & Public elementary school \\
\hline
\end{tabular}

This study involved a total of fifteen teachers of English from MGMP (Musyawarah Guru Mata Pelajaran or English Teachers Working Group) of Bandung Regency. They all voluntarily participated in the program. Out of these fifteen teachers, fourteen were junior high school teachers, and one was an elementary school teacher. Their ages ranged from 29 to 53 years old, and their teaching experiences spanned from just a year to around 24 years. Four of the teachers taught in private schools, while the rest taught in public schools. From the fifteen involved, only three are male teachers. More detailed profiles of the teacher participants are shown in Table 1 below. The participants' names have been given pseudonyms.

In analyzing the teachers' written assignments, we adopted content analysis (Hsieh \& Shannon, 2005), in which we scrutinized the appropriacy of the teachers' selected texts and the suitability of their designed instructional activities to each of the four CT stages which include (1) situated practice, (2) overt instruction, (3) critical framing, and (4) transformed practice. In examining, the appropriateness of the teachers' texts, we looked at the texts from three angles: (1) language level, (2) literary text type, and (3) text mode. In relation to the first category, which related to the linguistic aspect, we evaluated whether the teachers had chosen the right language level for their students. For this, we referred to the current curriculum for guidelines. As for the second category, we identified the type of the literary texts, whether it was 'prose' or 'poetry'. Regarding the third category, text mode, we looked at whether the text was in the form of a written text or some other 
modes, such as a video. This was important to note because we also wanted to take into account the multiliteracy nature of today's classroom.

\section{Findings and Discussion}

\subsection{Appropriateness of the Teachers' Texts}

As our community service program was aimed at promoting the development of critical thinking skills through literature, the teacher participants were thus required to use literary texts to design their instructional activities. The form and mode of the literary texts were not limited to a specific kind; rather, the notion was to be interpreted in its broadest sense, ranging from poems to song lyrics (despite the current debates on whether song lyrics can be considered literature). In scrutinizing the appropriateness of the teachers' texts, we looked at the texts from three angles: (1) language level, (2) literary text type, and (3) text mode. In relation to the first category, which related to the linguistic aspect, we evaluated whether the teachers had chosen the right language level for their students. For this, we referred to the current curriculum for guidelines. As for the second category, we identified the type of the literary texts, whether it was 'prose' or 'poetry'. Regarding the third category, text mode, we looked at whether the text was in the form of a written text or some other modes, such as a video. This was important to note because we also wanted to take into account the multiliteracy nature of today's classroom.

The 2013 Curriculum for junior high school outlines that one of the standar kompetensi students are expected to attain in the English language classroom is the ability to read and comprehend a simple short essay, be it in the form of procedure, descriptive, recount, report or narrative texts. In view of this "simple short essay", all of the teacher participants can be said to have selected the appropriate language level for their students. The length of their texts was around 200-300 words. However, in terms of text type, three out of the fifteen teachers chose wrong texts, as these texts were not classified as literary. Ela, Permatasari and Vira mistakenly selected report texts instead and presented Citarum river, bullying and the pandemic as their respective topics. As for the other twelve texts, which were literary, nine were prose, taking the form of short stories, and three were poetry (or poetry-like), two of which were song lyrics. Out of the nine short stories, three can be considered as fables, since they had animals as characters, two were folktales, raising the legends of Sangkuriang and Surabaya, and one was a myth, telling the story of Ramayana. In relation to the text mode, only one teacher presented the text in the form of a video, while the rest chose the traditional format of a plain written text.

In the following sub-sections, we present a stage-by-stage evaluation of the teachers' instructional activities which they had designed by drawing on Bobkina and Stefanova's model for teaching critical thinking skills. To reiterate, this model comprises four main stages: (1) situated practice, which includes pre- and post-reading activities, (2) overt instruction, which requires students to be engaged with the 'inner logic' of the text, (3) critical framing, which seeks to connect the text and context, and (4) transformed practice, which opens up the space for students to be creative and comes up with their own texts. This model reflects the required explicit teaching in developing critical thinking as suggested by Abrami et al. (2015) and Lai (2011).

\subsection{Appropriateness of the Teachers' Situated Practice (Stage 1)}

As previously mentioned, the main function of the first stage, situated practice, is to "activate students' schemata" (Bobkina \& Stefanova, 2016, p. 687) on the topic. To achieve this objective, the CT model requires teachers to engage students in a set of pre-reading activities. While most of the teacher participants included pre-reading activities in their instructional activities, two teachers, Ari and Tika, failed to incorporate this stage of situated practice, skipping both the pre- and post-reading activities in their planned instruction. The data revealed that a popular strategy to stimulate students' prior knowledge is through pictures. It was a common practice for all of the teachers who had prereading activities to provide relevant pictures before going through the actual text under discussion in Stage 2. They also provided questions to these pictures to guide the students' discussion. The questions commonly combine 'factual' questions and those that sought students' opinions and experiences. Iin, for example, who chose to engage her students with a fable, presented a total of four pictures depicting local folklores, a fable and a western fairy tale as her pre-reading activities and included the following questions to encourage students' involvement: "Do you like reading or listening to stories?", "what is your favorite story?" 
However, the teacher participants in general seemed to have misunderstood the idea of 'postreading activities' as defined by the CT model. While the model referred to post-reading activities as activities that explore students' thoughts and feelings related to the ideas contained in the main text, the teachers' post-reading activities simply revolved around the pictures given in the pre-reading activities. A number of teachers skipped the post-reading activities altogether and moved straight to the next stage, that is, overt instruction.

\subsection{Appropriateness of the Teachers' overt Instruction (Stage 2)}

As outlined by the model, the overt instruction stage focuses on close reading of the text. It requires students to exhibit an in-depth understanding of the text, comprehending its structure, the general idea, main ideas of each paragraph and the language details. This stage is about understanding the 'inner logic' of the text. All of the teacher participants involved comprehension questions in this stage, which required students to scrutinize the text. These questions were often formulated using the wh-questions. Some of the comprehension questions did not only ask students to look for information directly stated in the passage, but they also encouraged them to make inferences. Endah, for instance, who chose the legend of Sangkuriang as her literary text, included this in her reading questions: "Was Sangkuriang a bad son?" While there were hints in the passage regarding the kind of person Sangkuriang is, the students had to make their own judgments to answer the question. One common mistake made among the participants was not paying attention to the coherent sequencing of the questions, in which the easier questions should be presented first before asking more difficult ones. Such random formulation can not only discourage students from engaging with the text, it is also unreflective of the model adopted; to develop critical thinking skills, scaffolding is imperative (Bobkina \& Stefanova, 2016). An example of random formulation of reading questions can be seen in Leni's instructional design. Following her text that tells the story of Ramayana, Leni presented ten reading questions. Listed as number one, she asked the question, "how was Rahwana's character?", but then question number eight asked "where did the story take place?" This noncoherent sequencing of questions can be found in more than half of the teachers' instructional design. Another mistake, although less common, made by the teachers (i.e., Ayu, Endah, Nani, Tika) in the overt instruction stage is 'expanding' the questions to pictures presented in the pre-reading activities. Further, we also encountered a number of reading questions that are more suited to post-reading activities rather than the overt instruction stage. Such a 'mismatch' is evident in Tika's question of her short story that asks "do you like traveling by train?" Clearly, this question does not center on the text but is asking the students' personal preference.

Apart from reading questions, another popular activity employed by teachers in Stage 2 is vocabulary building. Nine teachers $(60 \%)$ incorporated activities that would help students to increase their new vocabularies. These activities commonly require students to define new words contained in the texts, to find synonyms, and to categorize words into their corresponding word classes; these vocabulary-building activities included word matching, crossword puzzle, and word search, among others.

\section{4. Appropriateness of the Teachers' Critical Framing (Stage 3)}

The CT model refers to critical framing as a stage that bridges the text to the wider sociocultural contexts, seeking relevance, for instance, between the ideas contained in the texts to the contexts in which the students are situated in. In this stage, the model emphasizes the important role of the teacher as the one who facilitates and directs the students' discussion. Critical framing is a very important stage in developing students' critical thinking skills as it provides the space for students to question, relate and compare, skillfully analyze and evaluate ideas embedded in the texts. The data, however, reveal that three teachers (Ari, Intan and Tika) missed this crucial stage in their instructional design. It was apparent that most teachers found this stage challenging, as they had to ask questions and create activities that would connect, borrowing Freire's phrase, the word and the world. All of the teacher participants who included critical framing had a question that directed students to thinking about 'the lessons learnt' from the texts, but very few of them went beyond this reflective activity. Some seemed to even repeat the general objective of Stage 2 and asked questions that required the students to look for information stated in the texts. Rather than connecting to the bigger sociocultural issues, many teachers posed reader-response questions that are more suited to the post-reading activities than the critical framing stage; these questions tend to revolve simply around 'the personal', seeking to identify the students' preferences and experiences, but they did not explore 'the social', 'the cultural' and 'the political'. 


\subsection{Appropriateness of the Teachers' Transformed Practice (Stage 4)}

According to the model, transformed a practice is a stage where students are given the space to be creative and evaluative, as manifested in the creation of their own texts. However, most teacher participants seemed to have misunderstood this objective; rather than encouraging students to create their own texts, most of the teachers asked them to retell or rewrite the text in their own words. This was a common misconception among the participants. Another common mistake made by the teachers appears to lie in the formulation of their instruction; they failed to make the instruction clear that they would require students to create a text of their own; instead, they only scratched the surface of this creative stage by inviting students to be imaginative. Apep, for example, who used the legend of Surabaya as his chosen literary text, simply asked students to imagine "what would happen if Sura won the fighting", rather than requiring students to write another version of the story. Similarly, Endah, whose text was about the legend of Sangkuriang, formulated this question in Stage 4: "what would happen if Sangkuriang could finish the boat?" Endah could have stated a more explicit instruction that would better fit this transformed practice stage, for example by asking students to create a continuation of the story or to expand and act out a particular part of the story. Only three teachers, Ela, Meti and Vera, indicated that they have understood the requirements expected in Stage 4. Meti asked her students to create their own poems relevant to the topic discussed, while Ela and Vera tried to engage their students in a video-making project.

A thorough analysis of the data indicated that the teacher participants, in general, do not seem to have fully grasped the concepts embedded in our proposed model. This is indicated in the various 'mismatches' between the stages and the activities they designed and their inability, in many cases, to fulfill the objectives of the four stages. The teachers' lack of understanding may be due to a number of reasons: (1) unfamiliarity with the literary genres, (2) insufficient time allocated for the workshop, and (3) insufficient time given to them to do the required task. The change from face-toface mode to an online mode was, indeed, very challenging for us, the instructors. Many modifications had to be made, and, due to technical problems and poor connection, we felt that we had not been optimal in delivering the materials. The online session, it turned out, could not substitute the face-to-face interaction. Our initial plan was to include teaching simulations done by some of the teacher participants, but this, too, had to be omitted due to the pandemic. However, further reflection on the teachers' difficulty to grasp the CT model pointed to their unfamiliarity to read and work with literary texts aesthetically, in which they overlooked the personal and affective dimensions of the text, hence failing to fully engage with the text.

Another misconception many teachers seemed to have is thinking they had to cover the four stages within one session of teaching. Consequently, the activities designed for the critical framing and the transformed practice stage tended to be superficial. None of the teachers designed activities that were project-based in the critical framing stage, which, in fact, would have been very useful in providing space for students to develop their critical thinking skills. However, as teachers, it appears that they have selected their texts quite carefully, presenting texts that were didactic in nature. The teachers' selection of texts appears to somewhat reflect a common conception generally held by Indonesian teachers that position them not only as 'knowledge transmitter' but also as 'moral guides' (see Gandana, 2014). It follows that 'lessons learnt' from texts appear to have become an important consideration for the teachers in selecting their texts.

The data also indicate that for the majority of the teachers' literary texts were merely seen as a tool to improve the students' linguistic competencies, rather than seeing them as valuable resources to develop critical thinking skills. This may be due to their unfamiliarity with the idea of incorporating critical thinking in their teaching activities. Although the teachers said that they often use narrative texts in the classroom, as this genre is part of the curriculum, it was apparent from their designed activities that promoting critical thinking skills does not seem to be their priority. The teaching of literature, instead, is perceived as a linguistic device to develop students' vocabulary, grammar mastery and reading skills, such as drawing factual information from the texts. Only a few teachers saw literature as an opportunity to open up a space to enhance the students' empathic skills and to make connections with the students' real-life situations. In Western academia and in many other EFL academic contexts, however, literature has made itself a way into the language curriculum and often been regarded as an effective tool to develop students' critical literacy (Aloqaili, 2011; Gillespie, 1994; Khatib \& Alizadeh, 2012). As American educator Tim Gillespie (1994) argues, "literature offers a different form of learning than just processing information; it requires us to 
experience, to participate. Works of literature are not just about human issues; the power of literature is that it makes issues come alive for the reader" (p. 20). Literature, Gillespie points out, provides a space for readers to "explore human experience in all its dimensions and possibilities" (ibid.), thus having the capacity to spark imagination, develop empathy, enhance creativity and critical thinking abilities.

Furthermore, the findings imply that the teachers have not had adequate knowledge and practice in teaching critical thinking. Similar to Ilyas' (2018) study, the teacher participants are all familiar with the term 'critical thinking' and the concepts related to Bloom's Taxonomy. However, in practice, they still have difficulties in transforming their knowledge critically, which suggests a diverse conception and implementation of critical thinking (Saleh, 2019). The findings, thus, bring to mind arguments put forward by Fahim and Masouleh (2012) and Lai (2011) who highlight the importance of teacher training to teach critical thinking. Since it is indispensable that teachers scaffold students' critical thinking, they must be trained to have greater success in developing this skill.

\section{Conclusion}

This study has explored the extent to which a group of English teachers demonstrated an understanding of how to implement a practical model for teaching critical thinking skills as reflected in their planned instructional activities. The data analysis reveals that, generally, the teachers have not fully grasped the concepts embedded in the proposed model and find incorporating activities that develop students' critical thinking challenging. The teachers, in particular, find it challenging to find ways to connect the text to context, facilitating students to 'read the word and the world'. While attempts have been made to establish personal engagement in students, as evident in the questions that explore students' voices and experiences, many teachers apparently find it difficult to relate issues contained in the literary texts to wider sociocultural and political contexts where students are situated in. Although a number of the teachers involved indicated that they understood what critical literacy is, many seem to be grappling with finding ways of how to skillfully and systematically do it at the practical level. This study, therefore, recommends that teachers be given more opportunities to explore the concepts surrounding critical literacy pedagogy, be facilitated in the engagement of professional development activities (i.e. in-service training), as well as be given more opportunities to do teaching simulation for practical application of the promoted instructional model.

\section{Acknowledgment}

The authors would like to extend their gratitude to the MGMP Bahasa Inggris Sub Rayon 5 for their valuable contribution to this research.

\section{Declarations}

Author contribution : The authors confirm sole responsibility for the following: study conception and design, data collection, analysis and interpretation of results, and manuscript.

Funding statement $\quad$ : The research is funded under no research project.

Conflict of interest $\quad$ : The author declares no conflict of interest.

Additional information: No additional information is available for this paper.

\section{REFERENCES}

Abrami, P., Bernard, R., Borokhovski, E., Waddington, D., Wade C., \& Persson, T. (2015). Strategies for teaching students critically: A meta-analysis. Review of Educational Research, 85(2), 275-314. https://doi.org/10.3102/0034654314551063 
Abudlridha, Q. A., \& Latiff, A. A. H. (2020). Assessing Iraqi university readers' critical thinking development through the use reader response strategy in the instruction of Shakespeare's literary text. Humanities and Social Sciences Reviews, 8(2), 123-133. https://doi.org/10.18510/hssr/2020/8215

Ahmad, T., Zainal, B. Z., \& Rajab, A. B. (2019). A conceptual review of the role of teaching and learning of second language through literature and communicative approach. Open Journal of Science and Technology, 2(2), 6-10.

Aloqaili, A. (2011). The relationship between reading comprehension and critical thinking: A theoretical study. Journal of King Saud University - Languages and Translation, 24, 35-41.

Bobkina, J., \& Stefanova, S. (2016). Literature and critical literacy pedagogy in the EFL classroom: Towards a model of teaching critical thinking skills. Studies in Second Language Learning and Teaching, 6(4), 677-696. https://doi.org/10.14746/ss1lt.2016.6.4.6

Bustami, Y., \& Corebima, A. (2017). The effect of JiRCA learning strategy of critical thinking skills of multiethnic students in higher education, Indonesia. International Journal of Humanities Social Sciences and Education (IJHSSE), 4(3), 13-22. https://dx.doi.org/10.20431/2349-0381.0403003/

Deering, C. G. (2018). Using literature to teach crisis intervention. Psychology Learning \& Teaching, 17(3), 73-83.

Enciso, E., Enciso, D., \& Daza, M. (2017). Critical thinking and its importance in education: Some reflections. Rastros Rostros, 19(34), 78-88. doi: https://doi.org/10.16925/ra.v19i34.2144

Facione, P. (2015). Critical thinking: What it is and why it counts. Measured Reasons LLC. https://www.measuredreasons.com/index_htm_files/what\&why2015.pdf

Fahim, M., \& Masouleh, N. (2012). Critical thinking in higher education: A pedagogical look. Theory and Practice in Language Studies, 2(7), 1370-1375. doi: 10.4304/tpls.2.7.1370-1375.

Freire, P., \& Macedo, D. (1987). Reading the word and the world. South Hadley, MA: Bergin \& Garvey.

Gandana, I. S. S. (2014). ELT, interculturality and teacher identity: An inquiry into Indonesian university teachers' beliefs and practices. Monash University, Australia.

Gillespie, T. (1994). Why literature matters. The English Journal, 83(8), 16-21. Retrieved from http://www.jstor.org/stable/820324.

Hasnunidah, N., Susilo, H., Irawati, M.H., Sutomo, H. (2015). Argument-driven inquiry with scaffolding as the development strategies of argumentation and critical thinking skills of students in Lampung, Indonesia. American Journal of Education Research, 3(9), 1185-1192. https://doi.org/10.12691/education-3-9-20.

Hsieh, H.-F., \& Shannon, S.E. (2005). Three approaches to qualitative content analysis. Qualitative Health Research, 15(9), 1277-1288. https://doi.org/10.1177/1049732305276687

Ilyas, H. (2015). Critical thinking; Its representation in Indonesian ELT textbooks and education. (Dissertation, University of York, 2015). Retrieved from:// https://etheses.whiterose.ac.uk/12688/1/Final\%20Thesis\%20-\%20Hamzah\%20Puadi\%20Ilyas.pdf.

Ilyas, H. (2018). Indonesian EFL teachers' conceptions of critical thinking. Journal of ELT Research, 3(1), 29-37. doi: 10.22236/JER_Vol3Issue1.

Khatib, M., \& Alizadeh, I. (2012). Critical thinking skills through literary and non-literary texts in English classes. International Journal of Linguistics, 4(4), 563-580. https://doi.org/10.5296/ijl.v4i4.2928

Küçükoğlu, H., \& Arikan, A. (2011). Prospective English language teachers' views on literature in their teacher education curriculum and its potential value. Procedia Social and Behavioral Sciences, 15, $1718-1722$.

Lai, E. (2011). Critical thinking: A literature review. Person Research Report. Retrieved from https://images.pearsonassessments.com/images/tmrs/CriticalThinkingReviewFINAL.pdf

Liao, H. (2016). Using complementary learning clusters in studying literature to enhance students' medical humanities literacy, critical thinking, and English proficiency. Psychological Reports, 118(2), 441465. https://doi.org/10.1177/0033294116636259 
Maknun, J. (2019). The development of critical thinking skills in vocational high school students in Indonesia. International Journal of Innovation, Creativity, and Change, 7(12), 237-258. https://doi.org/10.1177\%2F1475725717723837

Mok, F., \& Yuen, T. (2016). A critical evaluation of the understanding of critical thinking by school teachers: The case of Hong Kong. Citizenship, Social and Economics Education, 15(1), 28-44. https://doi.org/10.1177/2047173416652146

Nold, H. (2017). Using critical thinking teaching methods to increase students' success: An action research project. International Journal of Teaching and Learning in Higher Education, 29(1), 17-32. Retrieved from https://files.eric.ed.gov/fulltext/EJ1136016.pdf

Saleh, S.E. (2019). Critical thinking as a $21^{\text {st }}$ century skill: Conceptions, implementation, and challenges in the EFL classrooms. European Journal of Foreign Teaching, 4(1), 1-17. https://doi.org/10.5281/zonodo.2542838

Shpeizer, R. (2018). Teaching critical thinking as a vehicle for personal and social transformation. Research in Education, O(0), 1-18. https://doi.org/10.1177/0034523718762176

Solihati, N., \& Hikmat, A. (2018). Critical thinking tasks manifested in Indonesian language textbooks for senior secondary students. Sage Open, Juli-September 2018, 1-8. https://doi.org/10.1177/2158244018802164

Syahrial, Asrial, Kurniawan, D.A., Pratama, R.A., Perdana R. (2019). Towards the improving critical thinking skills of the pre-service teachers in Indonesia. Journal of Education and Learning (EduLearn), 13(4), 575-582. https://doi.org/10.11591/edulearn.v13i413613

Tabačkovà, Z. (2015). Outside the classroom thinking inside the classroom walls: Enhancing students' critical thinking through reading literary texts. Procedia Social and Behavioral Sciences 186, 726731.

Willis Allen, H., \& Paesani, K. (2010). Exploring the feasibility of a pedagogy of multiliteracies in introductory foreign language courses. L2 Journal, 2(1), 119-142. 